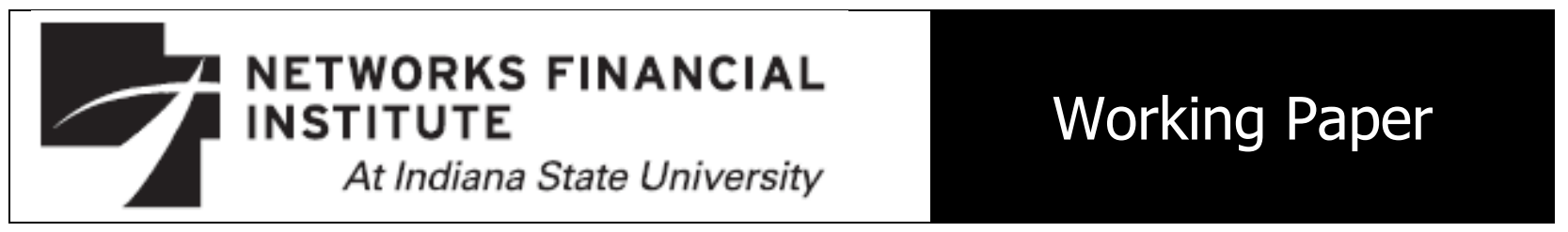

2012-WP-02

June 2012

\title{
Still Holding Out Promise: A Review of Financial Literacy Education and Financial Counseling Studies
}

\section{J. Michael Collins and Collin O'Rourke}

This paper was presented at NFI's May 14-15, 2009 conference in Indianapolis, IN entitled "Improving Financial Literacy and Reshaping Financial Behavior."

Abstract: This paper analyzes 26 studies that assess the impact of financial education and counseling targeted to low- and moderate-income consumers. Most studies report significant and positive findings, but the magnitude of impacts is often small compared to a control group. The evidence of behavior changes stemming from financial education is even weaker than the evidence of knowledge gains. Given the modest costs of delivering financial education, even these small impacts may be sufficient to support public policies facilitating financial education. Further research is needed to better understand how financial education can impact behavior, particularly by combining delivery methods and employing more personalized coaching-style models.

About the Authors: Michael Collins is faculty director of the Center for Financial Security at the University of Wisconsin, Madison. He is a faculty affiliate of the Wisconsin Cooperative Extension, the Institute for Research on Poverty, and the La Follette School of Public Affairs. Collins studies consumer decision-making in the financial marketplace, including the role of public policy in influencing credit, savings and investment choices. His work includes the study of financial capability with a focus on lowincome families. He directs the Social Security Administration Financial Literacy Research Consortium site at Wisconsin, a 5 year multi-disciplinary project focused on financial literacy for vulnerable populations. $\mathrm{He}$ is also working on projects related to mortgage foreclosure supported by the John $\mathrm{D}$ and Catherine $\mathrm{T}$. MacArthur foundation, as well as work on financial counseling and coaching supported by the Annie E. Casey foundation. Collins brings nearly a decade of applied experience to his research. He founded PolicyLab Consulting Group, a research consulting firm working with national foundations and government agencies, and co-founded MortgageKeeper Referral Services, an online database for mortgage servicers and counselors. He also worked for NeighborWorks America (Neighborhood Reinvestment Corporation) and the Millennial Housing Commission. He holds a Masters from the John F. Kennedy School of Government, a PhD from Cornell University, and a BS from Miami University (OH). Collin O'Rourke is an outreach specialist with the Center for Financial Security at the University of Wisconsin, Madison. In 2009, Collin graduated with a master's degree from UW-Madison's La Follette School of Public Affairs, where he focused on policy analysis and program evaluation. Collin graduated from UW-Madison with a BA in 2008. He majored in sociology and legal studies and completed a certificate in criminal justice.

The views expressed are those of the individual author and do not necessarily reflect official positions of Networks Financial Institute. Please address questions regarding content to Michael Collins at jmcollins@wisc.edu. Any errors or omissions are the responsibility of the authors. NFI working papers and other publications are available on NFI's website (www.networksfinancialinstitute.org). Click "Thought Leadership" and then "Publications/Papers." 


\section{Still Holding Out Promise: A Review of Financial Literacy Education and Financial Counseling Studies \\ J. Michael Collins and Collin O'Rourke}

\section{BACKGROUND}

In 2008 the President's Advisory Council on Financial Literacy was formed to increase the level of financial literacy among Americans (Executive Order no. 13455). Of the five major issues considered by the Council, two were related to understanding how education improves literacy and what methods of service delivery are most successful for specific audiences (President's Advisory Council on Financial Literacy 2008). The formation of this high-level commission underscores the recent interest in and focus on financial education for consumers, as well as a focus on the outcomes of financial education. As financial products and services have evolved, consumers are increasingly required to manage relatively sophisticated financial decisions, from individual retirement investment options to complex mortgage loans. Numerous studies have documented that consumers lack an understanding of basic personal finance concepts including compound interest, risk and return (for example Campbell 2006; Mandell 2004). Several public policies mandate aspects of financial literacy training, such as bankruptcy, food assistance programs and subsidized housing. Policymakers frequently refer to financial literacy education as a component of policy solutions for problems ranging from low savings rates to poor use of retirement accounts and mortgage foreclosures (for example, see Bernanke, 2006). Despite this durable rhetoric, there is a paucity of research about the effects of financial education, even though more rigorous research has been suggested for much of this decade (see Greenspan, 2002; GAO, 2004). This paper reviews recently published studies with the goal of synthesizing the findings to develop implications across papers for policy, practice and future research. It is hoped the existing literature can help inform new approaches and methodologies, or at least help shape new areas of inquiry. 


\section{PRIOR LITERATURE}

Although many published studies include careful literature reviews, none provide a comprehensive assessment of the entirety of research on adult financial literacy education and financial counseling, and none have categorized, analyzed and synthesized the results of prior studies as this study attempts to do. There are several highly useful literature reviews which serve as a foundation for this study, however. Hogarth (2006) reviewed 23 published and unpublished studies in a conference paper. The author provides a useful table summarizing studies and laying out a concise description of how financial education could be modeled to impact behavior. Hogarth's paper shows the breadth of the programmatic strategies that can be included within a broad definition of financial education and counseling, but it does not provide detailed comparisons of programs or methodologies. Martin (2007), in a Federal Reserve working paper, provides an overview of a subset of papers related to retirement education, school-based financial education, credit counseling and homebuyer education. The author concludes the field is still too new to have definitive studies, but that existing evidence is promising. Another Federal Reserve working paper by Hathaway and Khatiwada (2008) is less optimistic. These authors review many of the same papers and suggest evaluation is sorely lacking and there is little evidence of effects of financial education or counseling on behavior. The authors caution financial education studies too often suffer from selection effects- that is the participants in these studies are not randomly assigned but instead voluntarily partake in programs. The act of seeking out and completing education or counseling may be endogenous with the outcomes being measured in unobserved ways. Completing education thus becomes a proxy for unobserved motivation or other factors that also might facilitate positive behavior changes or knowledge gains. These authors conclude the results of most financial education and 
counseling studies are less than convincing.

Caskey (2006) provides one of the most careful and insightful reviews of five studies that are commonly used as justifications of the positive impacts of financial education or counseling. His analysis finds all five studies suffer from serious flaws. In addition to selection bias, which he describes as serious problem, these studies are not generalizable beyond the populations studied and do not span a long enough time period to provide proof of lasting behavioral impacts. Willis (2008a, 2008b) recently wrote multiple articles about financial education and provides one of the most critical reviews of the literature by a non-economist. She examines over 20 studies and concludes the overall evidence of financial education's effectiveness is weak at best. She further concludes that researchers seem to have a bias towards making marginal results appear more robust and statistically significant than is supported by the data. The author again identifies selection biases a problem, as well as small sample sizes. Willis concludes there is no evidence financial education is effective, perhaps a more negative interpretation than other authors who suggest that better research methods are needed. ${ }^{1}$

Meier and Sprenger (2007) provide strong evidence that selection bias likely undermines non-experimental studies. The authors offered a short credit education workshop at a tax preparation site to 800 lower-income tax filers. All respondents also completed a set of time preferences questions. The authors found those people who were most future-oriented were also the most likely to agree to attend the education session. Those who were most present-oriented were least likely to attend. The authors conclude "measured effects of treatment are therefore biased and the direction of the bias is towards the overestimation of positive effects" (p. 13, emphasis added).

\section{METHODOLOGY}


Quercia and Wachter's (1996) paper on homeownership counseling in many ways provides a model for this paper. The authors review more than a dozen studies conducted over a 20 year period on homebuyer education and mortgage counseling. After attempting to summarize and synthesize the methods and results of these studies, they use the data from these studies to suggest improvements for future research. Our analysis is based on 26 papers written since 1995 .

Only papers with an emphasis on basic financial education or counseling intended for low- and moderate-income consumers were considered. This is based on our prior belief that people of lower socio-economic and educational status are among the most vulnerable to financial problems. Financial mistakes may be more costly relative to income and may also require a longer recovery process for lower-income populations. While financial illiteracy, mistakes and naïveté are by no means isolated to lower-income adults, our view is that from a policy perspective of safeguarding vulnerable populations, as well as on the grounds of social equity, this population deserves the focus of financial education efforts. Certainly preventing financial illiteracy through youth financial education is also critical, but given the millions of existing adults for whom the educational system did not convey such knowledge, remedial efforts will be a priority for some time to come.

Due to our focus on lower-income adults, papers on retirement education were generally excluded. Programs aimed at retirement planning often focus on a particular employer and specific investment products. Employees educated in retirement programs are often professionals with moderate to high incomes. The content often focuses on technical aspects of retirement accounts and investment options. Similarly, youth programs, including school-based curricula, were excluded from this review. These programs appear to be highly heterogeneous in goals and 
design. Like the studies about retirement programs, it is unclear how the conclusions from studies of youth financial education could be feasibly blended with the more general adult financial literacy education and counseling covered in other papers. Only one study of retirement planning is included, largely due to the use of an innovative technique and the potential for a broadly applicable finding.

There is some debate in the literature about financial education's effects on learning versus behavior (for example see Lyons and Scherpf, 2004). Our focus is primarily on observable behavioral outcomes, especially measurable economic indicators such as savings, debt and credit. While clearly it is important to deliver education or counseling using pedagogical techniques which result in some form of learning, ultimately it is what consumers do with that knowledge which has implications for policy and the economy. Moreover, while having impact is necessary, the magnitude of the benefits of financial education policies must be sufficient to meet or exceed the social costs, including participants' time and energy.

The studies included in this analysis were based on literature searches including forward and reverse citation tracking. In each case, a paper was read, its citations were noted and the program's design, methodology and findings were recorded. In general articles published in peer-reviewed journals were included and unpublished works excluded.

\section{TYPOLOGY OF RESEARCH}

We have categorized papers by (1) methodology and (2) program type. Methodology includes descriptive studies (no controls or comparison groups), quasi-experimental studies (synthetic non-randomized controls) and experimental studies (random assignment to treatment and control). Program type includes both the focus of the education, such as homeownership or credit counseling, as well as the mode of delivery, such as workshops or telephone. Findings 
were summarized by calculating the largest statistical significant marginal effects over baseline whenever possible given the data published.

[Insert Table 1 about here]

SUMMARY OF THE AUTHOR, METHOD, AND IMPACTS OF FINANCIAL EDUCATION AND COUNSELING STUDIES

\section{Descriptive Studies}

Nine of the 26 studies utilize what we have labeled "descriptive" designs. These studies do not compare program participants to any type of comparison group. Each of these studies tracks changes in participants' financial literacy and/or behavior after participation in a program, though the data collection methods vary slightly across the studies. Typically this category of studies uses a two-period design, with a pre- and post- program test provided to clients. Eight of the nine studies report positive results, and the findings tend to be significantly larger than the findings in the quasi-experiments and experiments discussed below. The lack of a control group raises concerns that the outcome measures are not causally linked to the intervention, however.

A few aggregations within this category of studies are informative: The mean number of subjects in the nine descriptive studies is 909 , but the median is only 163 , largely due to one study with a large sample. Eight of the nine studies have less than 230 subjects. Overall the descriptive studies tend to have fewer participants than the other types of studies examined. These studies also tend to evaluate relatively small programs and use convenience samples. Seven studies analyze classroom-based financial education, one examines financial education and counseling delivered by telephone, and one analyzes face-to-face credit counseling.

These studies tend to rely on self-reported learning outcomes or behavior changes. Selfreports may be valid indicators, but may also be more subjective or even influenced by the 
educators involved. Secondary data also have problems, but are generally objective over time. Five of the nine descriptive studies analyze self-reported behavior changes after financial education programs. These five studies also have the highest impact estimates of all the studies in this review. One illustration of this type of study is Shelton and Hill's (1995) analysis of a homeownership education course. This article examines a financial education program for a small sample of 35 first-time homebuyers. The voluntary program consisted of six two-hour sessions that covered basic homeownership topics. Post-tests indicated dramatic shifts in participants' self-reported financial behaviors. For example, the number of participants who reported ensuring their income exceeds expenses "all of the time" increased by $50 \%$, as did the number who reported totaling the value of the things they owned "all of the time." In a similar study, DeVaney, Gorham, Bechman, and Haldman (1996) examined a financial education program for women that consisted of seven two-hour workshops. In surveys three months after the final session, participants' reported several significant improvements in their self-assessments of their financial behaviors. For instance, 55\% of the participants claimed they had developed or revised a spending plan due to the program. While these self-reported impacts seem large, there may be some situations where self-reports are appropriate.

Lyons and Scherpf (2004) examine a 10-module financial education program for lowincome individuals who lack bank accounts. The authors provide the important insight that opening a bank account after a financial literacy course may be an inappropriate outcome measure. Lyons and Scherpf note that for some low-income individuals managing a bank account and paying the related fees may in fact be more costly than remaining unbanked. Such a situation may bolster the argument in support of self-reported outcomes as a better indicator than a direct behavioral measure. The authors found $90 \%$ of participants agreed the program increased 
their financial knowledge and ability to manage their finances based on a follow-up survey.

Beyond self-reports and a lack of control group, descriptive studies may also suffer from attrition bias. For example, Haynes-Bordas, Kiss, and Yilmazer (2008) evaluate the Get Checking program. Get Checking is a financial education program for individuals who have previously been reported to ChexSystems for bank account abuse and mismanagement. The course lasted a range of three to six hours, and participants who completed the program were eligible to open bank accounts. Seventy-five percent of follow-up survey respondents reported they recorded transactions in their checkbooks more frequently after the program, and $91 \%$ had opened and maintained a checking account. Nevertheless, attrition may bias these findings due to low response rates to mailed surveys. It seems likely that clients who were successful in managing their finances and bank accounts were also more likely to be reachable and willing to reply to a survey. Responding to the survey may serve as a proxy for the motivation of the Get Checking participant, and could indicate the outcomes may have been achieved even in the absence of the educational program. Of course eliminating the number of follow-up data collection surveys may reduce attrition. For example, Lyons, Chang, and Scherpf (2006) examine a financial education program that consisted of eight one-hour sessions for low-income individuals. Participants completed only retrospective pre-tests (RPT). Eighty-five percent of respondents reported that participating in the program improved their financial management practices and five out of five financial behaviors in the RPT suggested improvements. Respondents providing the responses perceived as most desirable could be a further concern with this methodology.

Some descriptive studies focus primarily on learning outcomes. For example, Koenig's (2007) paper on financial education for incarcerated men documented mean financial literacy 
scores on a modified Jump\$tart financial literacy test increased by $12 \%$, subject to the biases of descriptive studies. Zhan, Anderson, and Scott (2006) analyze a set of financial education programs operated by 10 nonprofit agencies through the Financial Links for Low-Income People program in Illinois. Each site offered twelve-hours of basic financial education to individuals whose income was less than $200 \%$ of the poverty level. Participants' mean financial literacy scores increased by $37 \%$ from pre- to post-test. Knowledge specific to predatory lending practices and saving and investing increased by more than $40 \%$. In addition to the problems of selection and attrition, the nature of program resulted in highly heterogeneous programs across the 10 sites, making aggregation of results potentially problematic.

Lyons, White, and Howard (2008) are able to construct a difference-in-differences comparison of two treatments: individualized bankruptcy counseling and a bankruptcy education course. Participants' mean financial literacy scores increased by only $6.5 \%$ for the bankruptcy education group and 15\% for the bankruptcy counseling group, suggesting stronger impacts of individualized work. Because the treatments were not randomly designed, there is of potential selection bias. Nonetheless, it is unclear whether selection effects would explain differences in knowledge attainment from a baseline. More importantly, neither treatment was linked with changes in participants' financial behavior.

Birkenmaier and Tyuse's (2005) analysis of a 45 minute pre-purchase homeownership education and counseling session is the only descriptive study that lacks positive findings. After the one year follow-up period participants' mean credit score did not change. Compared to selfreported behavior changes and financial literacy test scores, Birkenmaier and Tyuse's analysis use of credit scores is arguably a more objective outcome measure, however. Given such a short intervention, effects on credit scores might not expected in any case. 
In general the descriptive studies suggest financial education yields large improvements in participants' financial knowledge and behaviors. Without a comparison group it is impossible to assess the actual impacts of these programs, however. It seems likely these studies overstate any potential program impacts if a comparison group could be identified. In addition, these studies tend to rely on self-reported data. Reliance on self-reports raises concerns about response bias (participants provide the desirable answer), or about educators providing clues for correct answers. Both would upwardly bias results. Because the multi-period studies rely on follow-up surveys, there is also the problem of attrition bias leaving only the most positive cases in the data, also generating in upwardly biased results. Finally, to the extent participants chose to attend these programs as opposed to being mandated to attend, there is the potential for selection bias. Enrolling in the program may in fact serve as a proxy for otherwise unobserved motivation, patience levels or other indicators of future financial improvements unrelated to the content of the program. Omitting variables which might indicate such selection could result in another form of upwardly biased results.

\section{Quasi-Experiments}

Thirteen of the 26 studies are quasi-experiments. In these studies, researchers identified a quasi-control group, modeled selection, or calculated the marginal effect of each additional hour of exposure to a program. The number of subjects in these studies ranges from 67 to 73,880 . The mean number of subjects is 10,413 , but the median is only 2,378 . The disparity between the mean and median reflects two outliers with large samples. Four of the studies had sample sizes of less than 300, five had samples of less than 1,000, and two had samples of more than 10,000. Twelve of the 13 studies report positive effects. Three studies utilized matched comparison groups, six utilized selection modeling, and three used exposure models. 
Two of the three studies with matched comparison groups suggest positive impacts of financial education. Wiener, Baron-Donovan, Gross, and Block-Lieb (2005) analyze a debtor education course for clients after bankruptcy. The authors identified two comparison groups, one of individuals in bankruptcy who did not take the course, or "untrained debtors," and another of non-debtors. Members of the treatment group, or "trained debtors," attended a 3-hour financial management course. Untrained debtors' and nondebtors mean financial literacy scores and financial behaviors did not change from pre- to post-testing. The treatment group's mean financial literacy score increased by $5.5 \%$, and the number of trained debtors who reported creating a budget increased by $50 \%$ compared to the baseline. Thus, the control groups' financial literacy and behaviors did not change, while the treatment groups' financial literacy and behaviors improved. Despite the use of two comparison groups, concerns about selection bias remain. The articles' descriptive statistics indicate significant differences in the composition of the trained and untrained debtor groups. The nondebtors are also markedly dissimilar from the trained debtors. The authors do not include statistical tests of the significance of these differences, nor do they comment on how these differences likely affected their findings.

Sanders, Weaver, and Schnabel (2007) use a similar matching design to examine a financial education program in two battered women's shelters. Women in two other shelters with similar structures and populations comprised the comparison group. While the comparison group's mean financial literacy score did not change from pre- to post-test, the treatment group's mean score increased by approximately $5 \%$. Together, these findings suggest that the curriculum yielded a small increase in the women's financial literacy. Due to the nature of this type of intervention, this study had high attrition and a small sample size. Additionally, the focus on such a targeted population in a crisis context raises questions about the generalizibility of the 
results. The third comparison group study, Braucher (2001), examines financial education's effect on bankruptcy completion rates. She compares debtors in cities that require a short bankruptcy financial education course for Chapter 13 debtors to debtors in similar cities with no such requirement. Debtors in the treatment group cities were $41 \%$ more likely to complete bankruptcy filing than debtors in the control group cities. Braucher notes that this finding is primarily attributable to uncontrolled local factors including differences in city-wide wages and filing costs rather than to the financial education requirement, however. Braucher's attempt to match similar cities failed to generate comparable pairs, and this study's findings are thus inconclusive.

The remaining seven studies all rely on modeled quasi-control groups using available data. The goal of this approach is to model and then control for which client select into education or counseling. Hirad and Zorn (2002) use selection modeling to examine the impact of prepurchase home ownership counseling on 90-day loan delinquency rates. Their dataset allowed them to compare different methods of counseling delivery, including in-person counseling, classroom-based counseling, home study, and counseling over the telephone. Before controlling for selection, classroom counseling, home study, and individual counseling in particular appear to reduce the probability of default, while telephone-based counseling has no effect. When selection is modeled, however, only classroom education is linked with a decline in foreclosure. The selection model's estimation suggests classroom-based counseling reduces borrowers' 90day delinquency rate by $94 \%$. This extremely large result and the design of the selection model casts doubt on these findings. It seems likely the characteristics of the loan and borrower used in the model to estimate which borrowers selected into counseling are not independent of the outcome of loan delinquency or default. Thus, the assumption that selection into homeownership 
education is not endogenous with the outcome is unconvincing.

Elliehausen, Lundquist, and Staten (2007) examine one-on-one credit counseling that was delivered in-person or over the telephone. The comparison group contained borrowers who lived in the same geographic location by zip code and had similar credit profiles as the treatment group but did not attend counseling. The initial analysis indicated that counseling led to significant improvements in credit scores. As may be expected, when the authors controlled for selection into counseling, the estimated effects decreased sharply. Among counseled borrowers in the lowest credit score quintile, credit scores increased by only three-fifths of one percent more than the comparison group. Counseled borrowers in this quintile also reduced revolving, consumer and total debt by approximately $10 \%$ more than non-counseled borrowers. There were no significant effects for people outside of the lowest credit score quintile, however.

In a pair of closely related studies Hartarska and Gonzalez-Vega (2005 and 2006) analyze a mortgage program that spanned several Midwestern states. The key difference between the two studies is their data sets, each of which covers a different time period. The loan program offered mortgages to low-income individuals and mandated that participants meet with a financial counselor. The counseling sessions were individualized and tailored to each participants' financial needs. The counseling program focused on cash flow, and participants were only eligible for a loan when they could generate zero or positive cash flow. Their 2005 study shows a small increase in borrowers prepaying their loans (generally refinancing for a lower rate, which could be viewed as a positive outcome). The 2006 study shows a 39\% lower default rates for counseled borrowers compared to non-counseled borrowers. This study relies on a selection model, however. Also, because of the nature of these specialized loan products, the effects could also be due to the loan terms rather than the counseling component. 
Ding, Quercia, and Ratcliffe (2008) examine phone-based counseling for moderately delinquent lower income mortgage borrowers. Counseling referral was proactive, and borrowers who were 45 days delinquent were contacted by mail and telephone. The counseling program's level of contact with each delinquent borrower ranged from no contact to a one-hour counseling session. The odds of curing the defaulted loan (that is getting caught up on payments) were $50 \%$ higher for borrowers who received counseling than for those who did not. This is also an unusual design, since education or counseling was offered to borrowers directly and in response to late payments. Moreover, the authors identify attrition and the potential for omitted variables as concerns about the quality of the selection model. It is likely the variables used to model which borrowers complied with the counseling offer are also related to the outcome of curing the loan.

Quercia and Spader (2008) utilize a selection model to analyze a range of pre-purchase homeownership education and counseling services. Their dataset tracked mortgage borrowers who purchased their first home between 1993 and 2003 until early 2006. They find no form of counseling affects default. Only intensive classroom-based counseling increases prepayment of mortgage loans, and only by 5.5\% (from 53\% to 56\%). Neither home study nor telephone counseling showed such an effect. However, the mode of counseling was not randomly assigned, so the potential for selection problems remains significant.

In a unique study, Spader, Ratcliffe, Skillern, and Montoya (2009) assess whether viewing a Spanish-language soap opera that incorporates financial literacy concepts affects Latino immigrants' financial literacy and behaviors. Participants in the treatment group were recruited at community events, and the control group was recruited by telephone. The reluctance of Latino immigrants to provide contact information made recruitment difficult, and attrition was high for both groups. The author's analysis includes propensity-score matching, which can be 
designed to rely on less strong assumptions about the independence of selection and the outcome of interest. The modeled impacts suggest viewers' composite financial literacy scores increased by only three-tenths of $1 \%$. Spader, Ratcliffe, Skillern, and Montoya's analysis shows the treatment group also made statistically significant gains on five of eight self-reported behaviors related to bank accounts and four of nine behaviors related to homeownership. The authors constructed two composite variables, one for behaviors related to bank accounts and the other for homeownership-related behaviors. Viewers' composite scores for both variables increased after watching the program, and each composite variable was significant at $\mathrm{p}<.01$.

Three quasi-experimental studies utilize exposure modeling, in which researchers seek to establish a dose-response relationship between the level of exposure to a program and the outcome measures. Exposure models generally provide estimates of the marginal impact of each additional hour of exposure to a program. The number of participants in these three studies ranges from 299 to 4,274 . The mean number of participants is 2,317 , and the median is 2,378 . One study examines a mandatory financial education course within an individual development account (IDA) program, while the two other studies examine financial counseling's impact on foreclosure.

Clancy, Grinstein-Weiss, and Schreiner (2001) analyze data from 14 IDA sites across the United States that partook in the American Dream Policy Demonstration. The low-income individuals who participated in the IDA programs were disproportionately female, AfricanAmerican, and never-married. The specific financial education program components and requirements, most notably the number of required hours, varied across the 14 sites. This variation allowed Clancy, Grinstein-Weiss, and Schreiner to estimate the effect of each additional hour of financial education on participants' average monthly net deposits (AMND) 
and on their deposit frequencies. From zero to six hours, each additional hour of financial education is associated with a $\$ 1.24$ increase in AMND, from seven to 12 hours a $\$ 0.54$ increase, and diminishing and inconsistent effects occur beyond 12 hours. From zero to 12 hours, each additional hour of financial education is associated with a $2 \%$ increase in deposit frequency, with non-significant marginal effects beyond 12 hours. Mean savings among participants with zero hours of financial education was $\$ 8.01$. Thus, the marginal effect estimates suggest six hours of financial education would increase AMND by approximately $93 \%$ to $\$ 15.45$. The mean deposit frequency among participants with zero hours of financial education was 39\%. Given the marginal effect estimate, one would predict six hours of financial education to increase deposit frequency by $12 \%$ points to $51 \%$. These are rough calculations that merely provide a sense the potential effects of financial education given the exposure models' results. Nevertheless, as the authors indicate, this study fails to disentangle selection effects from the program impacts. Clients who seek more counseling may in fact be the most motivated and prone to success. Given that the lack of exposure and the outcome of interest are not orthogonal, the marginal effects reported in their study almost certainly overstate financial education's effects.

Two recently published studies use exposure modeling to assess financial counseling's impact on foreclosure. Quercia and Cowan (2008) examine the Mortgage Foreclosure Prevention Program in Minneapolis, which provides case management, post-purchase counseling, and/or assistance loans to referred clients. For each additional hour the client spent with the program, the odds of avoiding foreclosure increased by $10 \%$. More specifically, homeowners who receive budget/credit counseling through the program were twice as likely to avoid foreclosure as those who did not. This study did not control for selection by number of hours, however. Collins (2007) analyzes financial counseling for mortgage borrowers in default. The data set includes 
clients in Chicago who received face-to-face and/or telephone-based counseling. The author then consulted public records to determine foreclosure outcomes six to nine months later. Because the number of hours in counseling could be endogenous with the loan outcome, the author constructed an instrumental variable using the number of marketing materials the City used to promote counseling services in each zip code. This instrument proved correlated with the number of hours in counseling but uncorrelated with individual foreclosures. The analysis indicates that each additional hour of counseling reduced the probability of negative foreclosure outcomes by 3.5\%. Collins cautions that the study's follow-up period was short and that the model's statistical significance of 0.10 is weak but the results are suggestive that each additional hour of financial counseling for borrowers in default may slightly reduce the probability of foreclosure.

Field Experiments

While randomized field experiments are the "gold standard" in research designs, field experiments comprise less than one in six of the studies we identify. Only four of the 26 studies in this review are field experiments in which individuals were randomly assigned to a treatment or control condition. Random assignment is one of the most reliable designs to establish a causal link between participation in a program and outcome measures. The mean number of subjects in the four experiments is 4,039 , and the median is 3,222 . The number of participants in these studies falls at two extremes. Two of the experiments have less than 250 subjects, and the other two have more than 6,000 . Three of the studies were published within the past six years, and one was still a working paper as of this writing. Each of the field experiments analyzes a different type of intervention, which impedes drawing general conclusions spanning all four studies.

Although Duflo and Saez's (2003) experiment does not directly focus on financial education or counseling, it is a good example of how a field experiment can be used to assess a 
program. This experiment was conducted at a university. Employees were randomly assigned to be offered $\$ 20$ in exchange for attending a retirement benefits seminar. First departments were also randomly assigned to be eligible to offer the inceptive to employees, and then individual employees were randomly assigned within the department to receive the incentive. Other employees in control departments did not receive any incentive offer. This assignment process allowed the authors to compare the enrollment rate of those who received the incentive to their departmental colleagues who did not receive it and to employees of departments in which no incentives were offered. This innovate research design allowed the authors to estimate the effects of social interaction on enrollment in the retirement program. Enrollment increased significantly among employees in treated departments, including both those who received the incentive and those who did not. Members of treated departments who did not receive the incentive enrolled in the retirement program at approximately the same rate as those who received the incentive. Compared to employees in control departments, employees in treated departments were $19 \%$ more likely to enroll in the retirement program after eleven months. This finding suggests social network effects can influence important economic decisions. The design shows how random assignment can be used even without withholding educational services from any clients. Inducements into treatment can serve a similar role.

In another example of an experimental design, Collins (forthcoming) examines a mandatory financial education program for a small sample of very-low-income families in a subsidized housing program. In this case the program was delivered to clients using a wait list procedure which was randomized. Collins uses a difference-in-differences comparison to compare outcomes between the treatment group who took the education in the first year and the control group who completed it one year later. The program consisted of five classes, and 
participants were tracked for 12 months. Estimated program impacts include a 21-point increase in credit scores, a 25\% improvement in financial knowledge, \$450 in additional savings, and a $48 \%$ improvement in self-reported financial behavior scores. These findings indicate that mandatory financial education programs, at least in a similar context with very low-income women in a subsidized housing program, can provide benefits that outweigh program costs. These results are based on a propensity score model in order to deal with a disproportionate share of the treatment group exiting the subsidized housing program in the year following the education. Because exiting the program could be related to the program and to the outcomes of interest, this process was important to understand. In fact, the results of the analysis became stronger once attrition was accounted for.

Although experiments are an optimal research design, implementation problems are common. The remaining two experiments' reviewed in this paper demonstrate several implementation difficulties. Gartner and Todd (2005) attempted to analyze online credit card education for credit cardholders who exhibit early warning signs of delinquency or whose accounts are delinquent. Cardholders were randomly assigned to a treatment group, which was referred by telephone to an online credit training site, or a control group, which was not. Nearly 10,000 cardholders were successfully reached by telephone, but less than 100 individuals logged onto the program's online education website. This take-up proved too low for additional analysis. More recently, Servon and Kaestner (2008) analyze a bank program which provided low- and moderate-income individuals in an inner city with a computer, internet access, computer training, and financial education. A quantitative analysis yielded non-significant program effects across a range of behavioral measures. The authors attribute the non-significant findings to the program's pilot status and inconsistent implementation. They cite attrition, imperfect randomization, and 
the program's short duration as factors that also likely diminished program effects. Servon and Kaestner provide detailed qualitative evidence to support their contention that poor and inconsistent implementation hindered the program's impact.

\section{Analysis by Content and Mode}

While linking methodologies to impact estimates is important, it is also useful to understand the program formats and the context in which the programs were delivered. These factors also play a role in evaluation design and in the determination of impacts. Tables $2,3,4$ and 5 provide a summary of the studies by methodology and mode of delivery aggregated in various combinations, none of which are mutually exclusive. Of the 26 studies reviewed for this paper, 15 analyzed financial education programs, and 15 evaluated programs delivered in classroom settings. Of the 15 classroom-based programs, 13 were financial education programs, and two were financial counseling programs. Admittedly, counseling and education may be blended in some programs and some studies examined multiple modes of delivery, but overall the emphasis was on classroom education. Positive effects were suggested by authors across modes and methods.

Another consideration is the delivery of financial education or counseling in person or on the telephone or internet. As shown in Table 2, only one study examines internet delivery (Gartner and Todd 2005). This study failed to produce useful data due to low take-up rates. Six studies examined programs delivered by telephone. Indicative of the recent focus on using technology to deliver counseling, all of these studies were published within the past seven years. Two of these studies focused on programs that are exclusively delivered by telephone (Ding, Quercia, and Ratcliffe 2008; Lyons, White, and Howard 2008), two compare telephone-based programs to other delivery methods (Hirad and Zorn 2002; Quercia and Spader 2008), and two studies examine programs that are delivered by telephone and/or in person without explicitly 
finding any difference in delivery methods (Collins 2007; Elliehausen, Lundquist, and Staten 2007). Five of these studies were based on financial counseling as opposed to education, and four of the six find positive results for telephone-based services.

[Insert Table 2 about here]

Table 3 shows that four of the six studies about telephone-based programs are quasiexperiments that utilize selection modeling, one quasi-experiment uses exposure modeling, and one study is a descriptive study without a control group. Both Hirad and Zorn (2002) and Quercia and Spader's (2008) analyses compare telephone-based pre-purchase counseling to home study, in-person counseling, and classroom-based counseling. Both of these studies use selection modeling. These studies find positive effects for other forms of counseling but not for telephonebased counseling in at least one set of models. Ding, Quercia, and Ratcliffe (2008) and Lyons, White, and Howard (2008) focus on counseling programs delivered exclusively by telephone. The paper by Ding, Quercia, and Ratcliffe on a proactive mortgage default counseling program that lasted up to one hour had the strongest results: borrowers who received counseling were $50 \%$ more likely to begin paying loans in default on-time. Lyons and White's descriptive study finds counseled borrowers' mean financial literacy test scores increased by $15 \%$ from pre- to post-test, but the study lacks a control group. Collins (2007) and Elliehausen, Staten, and Lundquist (2007) examine financial counseling delivered in person and by telephone. Both studies' models do not distinguish individuals who received counseling in person or over the telephone. Collins suggests both methods have some positive effects, but because telephone counseling tends to be shorter in duration, it likely has smaller effects than face-to-face counseling. When Collins controls for counseling duration there is no difference in effects by mode. Overall, these results do not suggest telephone counseling is inferior to in-person 
counseling.

[Insert Table 3 about here]

Table 4 shows a summary of studies by content area. In addition to general financial education, nine of the 26 studies focused on programs related to homeownership. This literature is among the most cohesive; recent studies about homeownership programs consistently cite prior studies. While eight of the nine studies examine counseling, one study analyzes a homeownership education program (we acknowledge the distinctions between education and counseling may not be well-defined). Two of the homeownership studies are descriptive and use pre-post tests, two use exposure models, and the remaining five use selection models. Four studies examine pre-purchase counseling and five examine default counseling or post-purchase interventions for borrowers who are at risk of losing their homes. Problems with selection biases are commonplace, but the authors claim positive effects across methodologies.

\section{[Insert Table 4 about here]}

There are fewer studies about programs for individuals who are going through bankruptcy. The studies in this area find positive results across a variety of modes and methodologies. The bankruptcy-related programs studied tend to rely more on classroom education, although phone or one-on-one services are a growing form of delivery in this field.

\section{[Insert Table 5 about here]}

Table 5 shows the types of outcome measures used across the format of the program studied. Of the 26 studies in this review, 18 measured changes in behavior only, three measured changes in financial literacy scores only, and five measured both. Behavioral measures were based on self-reported data for 9 of the 23 studies that examined behavioral outcomes. Financial education programs were most likely to use self-reported behavioral outcomes. Counseling 
programs generally used secondary measures of behavior, driven in part by default prevention counseling programs where loan default is an easily available and highly relevant outcome measure. In fact, loan performance is a common behavioral outcome, accounting for seven of the 23 studies with any behavioral measures. It seems likely that studies use loan performance in part because of its accessibility, even though it may not be as comprehensive a measure as may be desired.

\section{DISCUSSION}

Taken in its entirety, the literature on the impacts of financial education and counseling still holds out promise as a policy and programmatic strategy for lower-income consumers in a variety of financial contexts. Nevertheless, the current state of the literature is far from conclusive and is prone to a number of methodological problems and biases. We organize our discussion around the implications for program and research design.

The programs studied in these papers include several common components: a module on budgeting, some attention to credit management/repair, a section in which terms are defined and processes are explained, and finally some advice on how to compare financial costs and make choices. These core components are not delivered in all programs, but most programs include the majority of these concepts. Yet, beyond these areas, these programs tend to be highly heterogeneous. In some cases even a single program may be implemented differently across delivery sites.

Clancy and Carroll's (2007) review of studies on pre-bankruptcy credit counseling provides a useful summary of studies related to credit counseling. The authors include a more complete discussion of the mode of delivery than other papers, including telephone, internet, individual and group counseling. The authors raise the important issue that perhaps the optimal 
delivery of financial information could include a complementary mix of modes, rather than substituting one mode for another. No current study has examined such a multi-mode approach, and this is one area deserving of more research. It may be the case that the impacts of financial education and counseling services are optimized when they meet each client's unique needs, rather than when they are delivered in a standardized format for a set duration.

The direct and indirect evidence suggests that financial education and counseling systematically attracts people with a range of risk and motivation profiles into services and/or into particular modes and durations of education and counseling. It seems likely that clients who can navigate logistical challenges to attend time-consuming face-to-face services are also among the most highly motivated. Programs could be designed to reflect this reality and match the service to the client and to the context. When education or counseling services are delivery may be as important as how the program is delivered to each client. While traditional financial educators may resist newer delivery modes including telephone and internet based services, or even simulations and interactive games, the evidence does not overwhelmingly suggest these delivery modes are inferior.

On the research design issue, the literature is filled with calls for more and better studies with better controls, more data and longer time frames. It is quite clear better studies are needed to improve financial education and counseling strategies. While efforts to improve the capacity of education programs to measure their outcomes are laudable, this is a separate issue from developing a causal evaluation. Just as high school educators may benefit from solid course assessment tools, so can many financial educators. But few educational advocates expect high school teachers to conduct extensive evaluations of the longitudinal impact of their teaching on changes in students' behavior. That work is left to large-scale, highly resourced research. It 
seems to us that financial education is in need of such an approach. Surveys and focus groups conducted by Lyons, Palmer, Jayaratne and Scherpf (2006) confirm the challenges facing financial educators in conducting evaluation or assessment studies. Perhaps the only solution is an externally managed, large-scale experimental study with multiple educational or counseling treatments over a range of client populations and a consistent control group. This will require substantial client incentives, strong forms of randomization and follow-up and a substantial budget. Such a long-term study has the potential to validate which forms of financial education or counseling provide the strongest impacts for targeted audiences. It could provide direct evidence of the efficacy of mandating education as part of many public programs or subsidizing it in specific contexts.

What might such a national financial education demonstration experiment look like? Fully designing such a study is beyond the scope of this paper, but a few elements may be illustrative. First, the experiment would focus on adults with low- and moderate-incomes and would deliberately oversample members of minority groups and non-native English speakers. It would thus target audiences commonly projected to be the most vulnerable to financial information deficiencies. Second, it would include a basic set of educational components, most notably budgeting, using financial services, managing credit and repairing credit. Regardless of the application, these basic 'building blocks' of financial literacy would be included. Third, participants would be randomly assigned to one of four service delivery modes: in person, over the telephone, on the internet or a combination of the prior three. Additional variations might include follow-up goal setting and coaching components. Fourth the sample would contain at least 10,000 participants and need a budget \$7-10 million based on a three year time frame, semiannual data collection and modest financial incentives for ongoing participation. Last, 
participants would mandated into the study from existing programs, including those applying for subsidized mortgages, foreclosure prevention assistance, bankruptcy filing, food assistance and subsidized housing. Of course, all of these details provide fodder for discussion and are intended primarily to begin a dialogue on how better evaluation research can be accomplished.

\section{CONCLUSIONS}

The overall evidence of the effects of financial literacy and counseling efforts on behavioral outcomes is promising but far from conclusive. The design of programs and research clearly matters. Too often non-standardized programs deliver services to highly heterogeneous populations. Clients are able to select into the type and duration of services, and only a subset of clients are reliably tracked over time. There is a need for more controlled studies using randomization, but it is unrealistic to expect such research to take place organically by program providers. The size and scale of a study that is required will take leadership and support from foundations and government.

This lack of research should not impede future efforts. From the literature we glean some insights about the need to test a variety of delivery modes across a range of populations and contexts. It is possible that current counseling models are delivered in such crisis moments (for example bankruptcy or foreclosure) that they fail to impact behavior significantly. Likewise, education models may be too shallow and lack opportunities for practice and follow-up. A more individualized approach, such as financial coaching, may have potential. In such a model, clients focus on performance improvement and self-actualized goal attainment with the support and facilitation of a coach. New models may also emerge after further experimentation and more rigorous studies.

Another area of future study could include programs that provide financial education 
unrelated to retirement planning in the workplace. As the 2008 Annual Report of the President's Advisory Council on Financial Literacy suggests, employer-based education may prove an important context for delivering education and counseling, especially to low-wage workers. Initial employment decisions, including signing up for benefits, create one opportunity. Pay increases, decreases and layoffs are additional times when financial education could be provided. One particularly compelling opportunity may be related to annual tax filing. As demonstrated by the efforts of Progress Through Business and other programs, linking workplace-based tax filing with access to financial education and ongoing coaching could prove another successful platform for improving financial literacy and financial behavior. 


\section{REFERENCES}

Bernanke, Ben S. 2006. Financial literacy. Testimony Before the Committee on Banking, Housing, and Urban Affairs of the U.S. Senate, May 23.

Birkenmaier, Julie, and Sabrina W. Tyuse. 2005. Does Homeownership Education and Counseling (HEC) Help Credit Scores? Journal of Social Service Research, 32 (2): 81-103.

Braucher, Jean. 2001. An Empirical Study of Debtor Education in Bankruptcy: Impact on Chapter 13 Completion Not Shown. The American Bankruptcy Institute Law Review, 9: 557-92.

Campbell, John Y. 2006. Household Finance. The Journal of Finance, 61 (4): 1553-1604. Caskey, John P. 2006. Can Personal Financial Management Education Promote Asset Accumulation by the Poor? Networks Financial Institute Policy Brief 2006-PB-06 (March).

Clancy, Margaret, Michal Grinstein-Weiss, and Mark Schreiner. 2001. Financial Education and Savings Outcomes in Individual Development Accounts. Working Paper No. 01-2, St. Louis, MO: Center for Social Development, Washington University.

Clancy, Noreen, and Stephen J. Carrol. 2007. Prebankruptcy Credit Counseling. Prepared for the National Institute of Justice.

Collins, J. Michael. 2007. Exploring the Design of Financial Counseling for Mortgage Borrowers in Default. Journal of Family and Economic Issues, 28 (2): 207-25. Paper.

DeVaney, Sharon A., Elizabeth E. Gorham, Janet C. Bechman, and Virginia A. Haldeman. 1996. Cash flow management and credit use: effect of a financial information program. Financial Counseling and Planning, 7: 71-80.

Ding, Lei, Roberto G. Quercia, and Janneke Ratcliffe. 2008. Post-purchase Counseling and Default Resolutions among Low- and Moderate- Income Borrowers. Journal of Real Estate Research, 30 (3): 315-44.

Duflo, Esther, and Emmanuel Saez. 2003. The Role of Information and Social Interactions in Retirement Plan Decisions: Evidence from a Randomized Experiment. Quarterly Journal of Economics, 118 (3): 815-42.

Elliehausen, Gregory, E. Christopher Lundquist, and Michael E. Staten. 2007. The Impact of Credit Counseling on Subsequent Borrower Behavior. The Journal of Consumer Affairs, 41 (Summer): 1-28.

Executive Order no. 13455, Federal Register 73, no 16: 4445-4447 (January 2008): 4445-4447.

Gartner, Kimberly, and Richard M. Todd. 2005. Effectiveness of Online "Early Intervention" Financial Education for Credit Cardholders. Washington, DC: Federal Reserve System Community Affairs Research Conference (April).

Greenspan, Alan. 2002. Financial literacy. Testimony Before the Committee on Banking, Housing, and Urban Affairs of the U.S. Senate, February 5.

Hartarska, Valentina, and Claudio Gonzalez-Vega. 2005. Credit Counseling and Mortgage Termination by Low-Income Households. Journal of Real Estate Finance and Economics, 30 (3): 227-43. . 2006. Evidence on the effect of credit counseling on mortgage loan default by lowincome households. Journal of Housing Economics, 15 (1): 63-79. 
Hathaway, Ian, and Sameer Khatiwada. 2008. Do Financial Education Programs Work? Federal Reserve Bank of Cleveland Working Paper No. 08-03 (April).

Haynes-Bordas, Rebecca, D. E. Kiss, and Tansel Yilmazer. 2008. Effectiveness of Financial

Education on Financial Management Behavior and Account Usage: Evidence from a

'Second Chance' Program. Journal of Family and Economic Issues, 29 (3): 362-90.

Hirad, Abdighani, and Peter Zorn. 2002. A Little Knowledge is a Good Thing: Empirical

Evidence of the Effectiveness of Pre-Purchase Homeownership Counseling. In Low-income

Homeownership: Examining the Unexamined Goal, eds. Nicolas Retsinas, Eric Belsky, 146-

174. Cambridge, Mass.; Washington, D.C.: Joint Center for Housing Studies; Brookings

Institution Press.

Hogarth, Jeanne M. 2006. Financial Education and Economic Development. Paper presented at the G8 International Conference on Improving Financial Literacy, November 29, 2006, Moscow, Russian Federation. http://www.oecd.org/dataoecd/20/50/37742200.pdf.

Koenig, Lori A. 2007. Financial Literacy Curriculum: The Effect on Offender Money Management Skills. Journal of Correctional Education, 58 (1): 43-56.

Lyons, Angela C., Yunhee Chang, and Erik M. Scherpf. 2006. Translating Financial Education

into Behavior Change for Low-Income Populations. Financial Counseling and Planning, 17 (2): $27-45$.

Lyons, Angela C., Lance Palmer, Koralalage S. U. Jayaratne, and Erik Scherpf. 2006. Are We Making the Grade? A National Overview of Financial Education and Program Evaluation. The Journal of Consumer Affairs, 40 (2): 208-235.

Lyons, Angela C., and Erik Scherpf. 2004. Moving from unbanked to banked: evidence from the Money Smart program. Financial Services Review, 13 (3): 215-31.

Lyons, Angela C., Tommye White, and Shawn Howard. 2008. The Effect of Bankruptcy Counseling and Education on Debtors' Financial Well-Being: Evidence from the Front

Lines. Houston, TX: Money Management International. http://creditcounseling.org/ HelpfulResources/ArticleLibrary.asp?ArticleID=56.

Mandell, Lewis. 2004. Financial Literacy, Financial Failure, and the Failure of Financial Education. Proceedings of the Academy of Financial Services Eighteenth Annual Meeting.

Martin, Matthew. 2007. A literature review on the effectiveness of financial education. Federal Reserve Bank of Richmond Working Paper No. 07-03 (June).

Meier, Stephan, and Charles Sprenger. 2007. Selection into Financial Literacy Programs: Evidence from a Field Study. Federal Reserve Bank of Boston Discussion Paper No. 075 (November).

President's Advisory Council on Financial Literacy. 2009. 2008 Annual Report to the President. Washington: DC: The Department of the Treasury.

Quercia, Roberto, and Spencer M. Cowan. 2008. The Impacts of Community-based Foreclosure Prevention Programs. Housing Studies, 23 (3): 461-83.

Quercia, Roberto, and Jonathan Spader. 2008. Does Homeownership Counseling Affect the Prepayment and Default Behavior of Affordable Mortgage Borrowers? Journal of Policy Analysis and Management, 27 (2): 304-25.

Quercia, Roberto G. and Susan M. Wachter. 1996. Homeownership Counseling Performance: How Can It Be Measured? Housing Policy Debate, 7 (1): 175-200.

Sanders, Cynthia K., Terri L. Weaver, and Meg Schnabel. 2007. Economic Education for Battered Women: An Evaluation of Outcomes. Affilia, 22 (3): 240-54. 
Servon, Lisa J., and Robert Kaestner. 2008. Consumer Financial Literacy and the Impact of Online Banking on the Financial Behavior of Lower-Income Bank Customers. The Journal of Consumer Affairs, 42 (2): 271-305.

Shelton, Gladys G., and Octavia L. Hill. 1995. First-time homebuyers programs as an impetus for change in budget behavior. Financial Counseling and Planning, 6: 83-91.

Spader, Jonathan, Janneke Ratcliffe, Peter Skillern, and Jorge Montoya. 2009. The Bold and the Bankable: How the Nuestro Barrio Soap Opera Effectively Delivers Financial Education to Latino Immigrants. The Journal of Consumer Affairs, 43 (1): 56-79.

U.S. Government Accountability Office. 2004. HIGHLIGHTS OF A GAO FORUM: The Federal Government's Role in Improving Financial Literacy. http://www.gao.gov/cgibin/getrpt?GAO-05-93SP.

Wiener, Richard L., Corinne Baron-Donovan, Karen Gross, and Susan Block-Lieb. 2005. Debtor Education, Financial Literacy, and Pending Bankruptcy Legislation. Behavioral Sciences \& the Law, 23 (3): 347-66.

Willis, Lauren E. 2008a. Against Consumer Financial Literacy Education. Iowa Law Review, 94 (1): 12

. 2008b. Evidence and Ideology in Assessing the Effectiveness of Financial Literacy Education. U of Penn Law School, Public Law Research Paper No. 08-08 (Feb).

Zhan, Min, Steven G. Anderson, and Jeff Scott. 2006. Financial Knowledge of the Low-Income Population: Effects of a Financial Education Program. Journal of Sociology \& Social Welfare, 33 (1): 53-74. 
${ }^{1}$ Of course this is a classic case of interpretation of hypothesis tests — whether the lack of a strong finding suggests failing to reject the hypothesis education has any effect versus failing to reject the hypothesis education has no effect. 
Table 1: Summary of the Author, Method and Impacts of Financial Education and Counseling Studies

\begin{tabular}{|c|c|c|c|c|c|c|}
\hline Author(s) & $\begin{array}{l}\text { Year } \\
\text { Published }\end{array}$ & Method & $\begin{array}{l}\text { Number of } \\
\text { Subjects }\end{array}$ & Intervention(s) & Caution(s) & Finding(s) \\
\hline Shelton and Hill & 1995 & $\begin{array}{l}\text { Descriptive } \\
\text { Pre-post }\end{array}$ & 35 & $\begin{array}{l}\text { Pre-purchase classroom financial } \\
\text { education for low and moderate- } \\
\text { income prospective first-time } \\
\text { homebuyers }\end{array}$ & $\begin{array}{l}\text { Selection bias, short duration, } \\
\text { self-report bias }\end{array}$ & $\begin{array}{l}+ \\
50 \% \text { increase in the proportion who reported totaling the value of the things they owned } \\
\text { "All of the time" } \\
33 \% \text { increase in the proportion who reported totaling the amount of their bills "All of the } \\
\text { time" } \\
51 \% \text { increase in the proportion who reported ensuring their income exceeds expenses "All } \\
\text { of the time" }\end{array}$ \\
\hline $\begin{array}{l}\text { DeVaney, } \\
\text { Gorham, } \\
\text { Bechman, and } \\
\text { Haldman }\end{array}$ & 1996 & $\begin{array}{l}\text { Descriptive } \\
\text { Pre-post }\end{array}$ & 196 & $\begin{array}{l}\text { Classroom workshops for women } \\
\text { that focus on financial management } \\
\text { skills }\end{array}$ & Attrition bias, selection bias & $\begin{array}{l}55 \% \text { developed or revised a spending plan } \\
67 \% \text { adopted the identification of spending leaks } \\
44 \% \text { started or added to an emergency fund }\end{array}$ \\
\hline Braucher & 2001 & $\begin{array}{l}\text { Quasi- } \\
\text { experiment } \\
\text { Matched cities }\end{array}$ & 7,746 & $\begin{array}{l}\text { Mandatory classroom financial } \\
\text { management course for chapter } 13 \\
\text { debtors }\end{array}$ & $\begin{array}{l}\text { Non-standardized intervention, } \\
\text { short duration, omitted variable } \\
\text { bias }\end{array}$ & $\begin{array}{l}\text { Regression analysis associates education with a } 12 \% \text { decrease in completion rate. } \\
\text { Debtors who received financial education had a Chapter } 13 \text { completion rate of } 41.9 \% \text {, } \\
\text { compared to } 29.6 \% \text { for those who did not, primarily due to local factors }\end{array}$ \\
\hline $\begin{array}{l}\text { Clancy, } \\
\text { Grinstein-Weiss, } \\
\text { and Schreiner }\end{array}$ & 2001 & $\begin{array}{l}\text { Quasi- } \\
\text { Experiment } \\
\text { Exposure model }\end{array}$ & 2,378 & $\begin{array}{l}\text { Classroom financial education } \\
\text { required by an individual } \\
\text { development account program. }\end{array}$ & Non-standardized intervention & $\begin{array}{l}+ \\
\text { From 0-12 hours, each additional hour of financial education increases average monthly net } \\
\text { deposits by one dollar and increases deposit frequency by two percentage points. Effects } \\
\text { level off and may reverse after twelve hours. }\end{array}$ \\
\hline Hirad and Zorn & 2002 & $\begin{array}{l}\text { Quasi- } \\
\text { experiment } \\
\text { Selection model }\end{array}$ & 39,318 & $\begin{array}{l}\text { Pre-purchase homeownership } \\
\text { counseling: classroom, home study, } \\
\text { individual, or telephone }\end{array}$ & $\begin{array}{l}\text { Non-standardized intervention, } \\
\text { omitted variable bias }\end{array}$ & $\begin{array}{l}+ \\
\text { Borrowers who receive counseling are, on average, } 19 \% \text { less likely to become } 90 \text { days } \\
\text { delinquent. When selection is controlled only classroom-based counseling is effective. } \\
\text { Home study, telephone-based counseling, and face-to-face counseling are not supported }\end{array}$ \\
\hline Duflo and Saez & 2003 & $\begin{array}{l}\text { Randomized } \\
\text { field experiment }\end{array}$ & 6,200 & $\begin{array}{l}\text { Cash incentive to attend an } \\
\text { employee benefits fair }\end{array}$ & & $\begin{array}{l}\text { Retirement plan's enrollment rate increased by } 1.25 \% \text { points after } 11 \text { months. } \\
\text { Being in a treated department increases the probability of attendance by } 10 \% \text { points, and } \\
\text { receiving a cash incentive increases the probability by another } 13 \% \text { points }\end{array}$ \\
\hline $\begin{array}{l}\text { Lyons and } \\
\text { Scherpf }\end{array}$ & 2004 & $\begin{array}{l}\text { Descriptive } \\
\text { Pre-post }\end{array}$ & 226 & $\begin{array}{l}\text { Classroom financial education for } \\
\text { the unbanked }\end{array}$ & $\begin{array}{l}\text { Attrition bias, selection bias, } \\
\text { omitted variable bias, self-report } \\
\text { bias }\end{array}$ & $\begin{array}{l}+ \\
90 \% \text { agreed that the program increased their financial knowledge and ability to manage their } \\
\text { finances, and that they will use what they learned. } \\
\text { Those who agreed they became more knowledgeable were } 22 \% \text { more likely to open an } \\
\text { account } \\
\text { Exposure to advanced lessons associated with } 20 \% \text { decline in the probability of opening an } \\
\text { account }\end{array}$ \\
\hline $\begin{array}{l}\text { Birkenmaier and } \\
\text { Tyuse }\end{array}$ & 2005 & $\begin{array}{l}\text { Descriptive } \\
\text { Pre-post }\end{array}$ & 203 & $\begin{array}{l}\text { One-on-one homeownership } \\
\text { education and counseling }\end{array}$ & $\begin{array}{l}\text { Attrition bias, omitted variable } \\
\text { bias }\end{array}$ & Non-significant change in credit scores \\
\hline $\begin{array}{l}\text { Gartner and } \\
\text { Todd }\end{array}$ & 2005 & $\begin{array}{l}\text { Randomized } \\
\text { field experiment }\end{array}$ & $\begin{array}{l}\text { 2 Experiments: } \\
\text { 1) } 6,417 \\
\text { 2) } 3,170 \\
\text { Right party } \\
\text { telephone } \\
\text { connects }\end{array}$ & $\begin{array}{l}\text { Online credit card education for } \\
\text { delinquent or at-risk borrowers }\end{array}$ & Attrition bias, selection bias & $\begin{array}{l}\text { 1) Take-up too low for analysis } \\
\text { 2) Take-up too low for analysis }\end{array}$ \\
\hline $\begin{array}{l}\text { Hartarska and } \\
\text { Gonzalez-Vega }\end{array}$ & 2005 & $\begin{array}{l}\text { Quasi- } \\
\text { experiment } \\
\text { Selection model }\end{array}$ & 919 & $\begin{array}{l}\text { Individualized pre-purchase credit } \\
\text { counseling }\end{array}$ & $\begin{array}{l}\text { Non-standardized intervention, } \\
\text { omitted variable bias }\end{array}$ & $\begin{array}{l}+ \\
\text { Mixed results, with small increases in prepayment and in default }\end{array}$ \\
\hline $\begin{array}{l}\text { Wiener, Baron- } \\
\text { Donovan, Gross, } \\
\text { and Block-Lieb }\end{array}$ & 2005 & $\begin{array}{l}\text { Quasi- } \\
\text { experiment } \\
2 \text { nonrandom } \\
\text { comparison } \\
\text { groups }\end{array}$ & 423 & $\begin{array}{l}\text { Classroom financial education for } \\
\text { Chapter } 7 \text { or } 13 \text { bankruptcy-filers }\end{array}$ & $\begin{array}{l}\text { Attrition bias, selection bias, } \\
\text { short duration omitted variable } \\
\text { bias, self-report bias }\end{array}$ & $\begin{array}{l}+ \\
\text { Trained debtors' financial knowledge test scores increased by } 4 \% \text { points from } 71 \% \text { to } 75 \% \\
\text { Proportion of trained debtors who reported paying all bills in the past month increased by } \\
89 \% \text { from } 37 \% \text { to } 70 \% \text {, and the proportion who reported creating a budget increased by } \\
50 \% \text { from } 42 \% \text { to } 63 \%\end{array}$ \\
\hline $\begin{array}{l}\text { Hartarska and } \\
\text { Gonzalez-Vega }\end{array}$ & 2006 & $\begin{array}{l}\text { Quasi- } \\
\text { experiment }\end{array}$ & 233 & $\begin{array}{l}\text { Individualized pre-purchase credit } \\
\text { counseling }\end{array}$ & $\begin{array}{l}\text { Non-standardized intervention, } \\
\text { omitted variable bias }\end{array}$ & $\begin{array}{l}+ \\
\text { Counseled borrowers had } 39 \% \text { lower default rates than non-counseled borrowers }\end{array}$ \\
\hline
\end{tabular}




\begin{tabular}{|c|c|c|c|c|c|c|}
\hline & & Selection model & & & & \\
\hline $\begin{array}{l}\text { Lyons, Chang, } \\
\text { and Scherpf }\end{array}$ & 2006 & $\begin{array}{l}\text { Descriptive } \\
\text { Retrospective } \\
\text { Pre-test }\end{array}$ & 161 & $\begin{array}{l}\text { Classroom financial education } \\
\text { provided by social service agencies }\end{array}$ & $\begin{array}{l}\text { Attrition bias, selection bias, } \\
\text { non-standardized intervention, } \\
\text { self-report bias }\end{array}$ & $\begin{array}{l}++ \\
85 \% \text { of participants reported improved financial management practices } \\
\text { All } 5 \text { measured financial behaviors improved, including a } 30 \% \text { point increase in participants } \\
\text { who always pay their bills on time, from } 30 \% \text { to } 60 \%\end{array}$ \\
\hline $\begin{array}{l}\text { Zhan, Anderson, } \\
\text { and Scott }\end{array}$ & 2006 & $\begin{array}{l}\text { Descriptive } \\
\text { Pre-post }\end{array}$ & 163 & $\begin{array}{l}\text { Basic classroom financial } \\
\text { management training provided by } \\
\text { social service agencies }\end{array}$ & $\begin{array}{l}\text { Selection bias, non-standardized } \\
\text { intervention, short duration }\end{array}$ & $\begin{array}{l}+ \\
\text { Composite financial knowledge scores increased by } 37 \% \\
\text { Knowledge of predatory lending practices increased by } 41 \% \\
\text { Knowledge of saving and investing increased by } 45 \%\end{array}$ \\
\hline Collins & 2007 & $\begin{array}{l}\text { Quasi- } \\
\text { experiment } \\
\text { Exposure model }\end{array}$ & 299 & $\begin{array}{l}\text { Telephone and/or face-to-face } \\
\text { financial counseling for borrowers } \\
\text { in mortgage default }\end{array}$ & $\begin{array}{l}\text { Attrition bias, short duration, } \\
\text { self-report bias }\end{array}$ & $\begin{array}{l}+ \\
\text { Each additional hour of counseling reduces the probability of foreclosure by } 3.5 \%\end{array}$ \\
\hline $\begin{array}{l}\text { Elliehausen, } \\
\text { Lundquist, and } \\
\text { Staten }\end{array}$ & 2007 & $\begin{array}{l}\text { Quasi- } \\
\text { experiment } \\
\text { Selection model }\end{array}$ & 73,880 & $\begin{array}{l}\text { Individualized credit counseling } \\
\text { delivered in person or over the } \\
\text { phone. }\end{array}$ & $\begin{array}{l}\text { Attrition bias, non-standardized } \\
\text { intervention, omitted variable } \\
\text { bias }\end{array}$ & $\begin{array}{l}+ \\
\text { Mean Emprica scores among counseled borrowers in the lowest quintile increased by } 65.34 \\
\text { points, to a level just } 0.63 \% \text { higher than non-counseled borrowers. No differences for } \\
\text { borrowers in the three higher quintiles } \\
\text { Counseled borrowers in the lowest score quintile reduced revolving debt, consumer debt, } \\
\text { and total debt by approximately } 10 \%\end{array}$ \\
\hline Koenig & 2007 & $\begin{array}{l}\text { Descriptive } \\
\text { Pre-post }\end{array}$ & 17 & $\begin{array}{l}\text { Classroom financial education } \\
\text { course for prisoners }\end{array}$ & $\begin{array}{l}\text { Selection bias, non-standardized } \\
\text { intervention, special population, }\end{array}$ & $\begin{array}{l}+ \\
\text { Financial literacy scores on a modified Jump\$tart test increased by } 12 \% \text { from } 66 \% \text { to } 75 \%\end{array}$ \\
\hline $\begin{array}{l}\text { Sanders, } \\
\text { Weaver, and } \\
\text { Schnabel }\end{array}$ & 2007 & $\begin{array}{l}\text { Quasi- } \\
\text { experiment } \\
\text { Site matching }\end{array}$ & 67 & $\begin{array}{l}\text { Classroom financial education for } \\
\text { battered women }\end{array}$ & $\begin{array}{l}\text { Attrition bias, omitted variable } \\
\text { bias, special population, self- } \\
\text { report bias }\end{array}$ & $\begin{array}{l}+ \\
\text { Experimental group's average financial literacy score increased by } 4.6 \% \text {, with a negligible } \\
\text { increase for the comparison group } \\
\text { Experimental group's financial self-efficacy score increased by } 11.4 \% \text {, with } 3.3 \% \text { decrease } \\
\text { for the comparison group }\end{array}$ \\
\hline $\begin{array}{l}\text { Ding, Quercia, } \\
\text { and Ratcliffe }\end{array}$ & 2008 & $\begin{array}{l}\text { Quasi- } \\
\text { experiment } \\
\text { Selection model }\end{array}$ & 2,975 & $\begin{array}{l}\text { Telephone financial and budget } \\
\text { counseling service for moderately } \\
\text { delinquent mortgage borrowers. }\end{array}$ & Omitted variable bias & $\begin{array}{l}++ \\
\text { Odds of curing } 50 \% \text { higher for borrowers who received counseling than for those who did } \\
\text { not, relative to foreclosure. Probability of curing in six months is } 18 \% \text { higher for borrowers } \\
\text { who receive counseling immediately after they enter a } 60 \text {-day delinquency }\end{array}$ \\
\hline $\begin{array}{l}\text { Haynes-Bordas, } \\
\text { Kiss, and } \\
\text { Yilmazer }\end{array}$ & 2008 & $\begin{array}{l}\text { Descriptive } \\
\text { Follow-up } \\
\text { survey }\end{array}$ & 160 & $\begin{array}{l}\text { Second chance classroom financial } \\
\text { education program for consumers } \\
\text { who abused or mismanaged } \\
\text { checking accounts }\end{array}$ & $\begin{array}{l}\text { Attrition bias, selection bias, self- } \\
\text { report bias }\end{array}$ & $\begin{array}{l}+ \\
68 \% \text { of the participants who owed restitution paid their debts within a month after earning } \\
\text { the certificate } \\
91 \% \text { had opened and maintained a checking account } \\
54 \% \text { had opened and maintained a savings account } \\
75 \% \text { changed their behavior in recording transactions }\end{array}$ \\
\hline $\begin{array}{l}\text { Lyons, White, } \\
\text { and Howard }\end{array}$ & 2008 & $\begin{array}{l}\text { Descriptive } \\
\text { Pre-post }\end{array}$ & $\begin{array}{l}4,310 \\
\text { counseling } \\
2,713 \text { education }\end{array}$ & $\begin{array}{l}\text { treatments: } \\
\text { Telephone bankruptcy counseling } \\
\text { and education }\end{array}$ & $\begin{array}{l}\text { Attrition bias, short duration, } \\
\text { self-report bias }\end{array}$ & $\begin{array}{l}+ \\
\text { Non-significant effects on financial behavior } \\
\text { Average financial knowledge score increased by } 6.5 \% \text { in the education group and } 15 \% \text { in } \\
\text { the counseling group. }\end{array}$ \\
\hline $\begin{array}{l}\text { Quercia and } \\
\text { Cowan }\end{array}$ & 2008 & $\begin{array}{l}\text { Quasi- } \\
\text { experiment } \\
\text { Exposure }\end{array}$ & 4,274 & $\begin{array}{l}\text { Foreclosure prevention counseling, } \\
\text { case management, and financial } \\
\text { assistance }\end{array}$ & Non-standardized intervention & $\begin{array}{l}+ \\
\text { For each additional hour the client spent with the program, the odds of avoiding foreclosure } \\
\text { increased by } 10 \% \\
\text { Homeowners who received pre-purchase counseling and education or who received } \\
\text { budget/credit counseling were twice as likely to avoid foreclosure }\end{array}$ \\
\hline $\begin{array}{l}\text { Quercia and } \\
\text { Spader }\end{array}$ & 2008 & $\begin{array}{l}\text { Quasi- } \\
\text { experiment } \\
\text { Selection model }\end{array}$ & 2,688 & $\begin{array}{l}\text { A range of pre-purchase } \\
\text { homeownership and education } \\
\text { counseling }\end{array}$ & Omitted variable bias & $\begin{array}{l}+ \\
\text { Counseling has non-significant effects on default. } \\
\text { Prepayment increased by } 3 \% \text { points from approximately } 53 \% \text { to } 56 \% \text {, a gain of } 5 \%\end{array}$ \\
\hline $\begin{array}{l}\text { Servon and } \\
\text { Kaestner }\end{array}$ & 2008 & $\begin{array}{l}\text { Randomized } \\
\text { field experiment }\end{array}$ & 243 & $\begin{array}{l}\text { Participants received computer, } \\
\text { internet access computer training, } \\
\text { and classroom financial education }\end{array}$ & $\begin{array}{l}\text { Attrition bias, selection bias } \\
\text { (imperfect randomization), short } \\
\text { duration, self-report bias }\end{array}$ & Non-significant effects \\
\hline $\begin{array}{l}\text { Spader, } \\
\text { Ratcliffe, } \\
\text { Skillern, and } \\
\text { Montoya } \\
\end{array}$ & 2009 & $\begin{array}{l}\text { Quasi- } \\
\text { experiment } \\
\text { Propensity score } \\
\text { matching }\end{array}$ & 171 & $\begin{array}{l}13 \text { telenovela episodes that } \\
\text { incorporate financial literacy and } \\
\text { homeownership concepts }\end{array}$ & $\begin{array}{l}\text { Attrition bias, selection bias, } \\
\text { omitted variable bias, self-report } \\
\text { bias }\end{array}$ & $\begin{array}{l}+ \\
\text { Program viewers scored } 3 / 10 \text { of } 1 \% \text { higher on the financial literacy index } \\
\text { Treatment group made statistically significant gains on } 5 \text { of } 8 \text { account usage variables and } 2 \\
\text { of } 9 \text { homeownership variables }\end{array}$ \\
\hline Collins & $\begin{array}{l}\text { Forthcom } \\
\text { ing }\end{array}$ & $\begin{array}{l}\text { Randomized } \\
\text { field experiment } \\
\text { Attrition } \\
\text { correction }\end{array}$ & 127 & $\begin{array}{l}\text { Mandatory classroom financial } \\
\text { skills training for low and } \\
\text { moderate-income families in a } \\
\text { subsidized housing program }\end{array}$ & Attrition bias, self-report & $\begin{array}{l}+ \\
21 \text {-point increase in credit score } \\
25 \% \text { improvement in financial knowledge } \\
\$ 450 \text { in additional savings } \\
48 \% \text { improvement in positive self-reported financial behavior }\end{array}$ \\
\hline
\end{tabular}

Table 2: Aggregated Synthesis of Studies by Methodology, Format and Mode

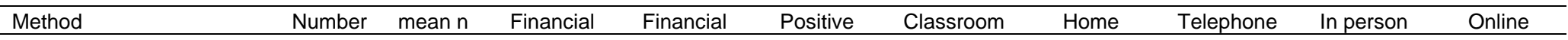




\begin{tabular}{lccccccccc}
\hline & $\begin{array}{c}\text { of } \\
\text { studies }\end{array}$ & & education & counseling & effects & & study & \\
Descriptive & $9^{*}$ & 909 & 8 & 2 & 8 & 7 & 0 & 1 & 0 \\
Quasi-experiment & 13 & 10,413 & 4 & 8 & 12 & 6 & 2 & 4 & 0 \\
Experiment & 4 & 4,039 & 3 & 0 & 2 & 2 & 0 & 0 \\
Total & 26 & & 15 & 10 & 22 & 15 & 2 & 0 \\
\hline
\end{tabular}

* 1 study looks at both counseling and education (Hirad and Zorn) 
Table 3: Aggregated Synthesis of Studies by Mode and Format

\begin{tabular}{|c|c|c|c|c|c|c|c|}
\hline Mode & Number of studies & Financial education & Financial counseling & Positive effects & $\begin{array}{l}\text { Descriptive } \\
\text { Method }\end{array}$ & $\begin{array}{c}\text { Quasi- } \\
\text { experiments }\end{array}$ & $\begin{array}{l}\text { Randomized } \\
\text { Experiments }\end{array}$ \\
\hline Classroom & 15 & 13 & 2 & 14 & 7 & 6 & 2 \\
\hline Home study & 2 & 0 & 2 & 0 & 0 & 2 & 0 \\
\hline Telephone & 6 & 1 & 6 & 4 & 1 & 5 & 0 \\
\hline In person & 8 & 0 & 8 & 6 & 1 & 7 & 0 \\
\hline Online & 1 & 1 & 0 & 0 & 0 & 0 & 1 \\
\hline
\end{tabular}

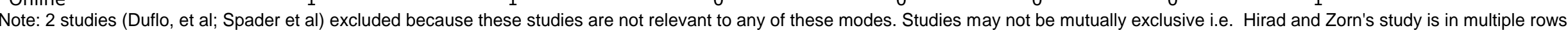


Table 4: Aggregated Synthesis of Studies by Content Methodology and Mode

\begin{tabular}{|c|c|c|c|c|c|c|c|c|c|c|c|c|}
\hline & $\begin{array}{l}\text { Number of } \\
\text { studies }\end{array}$ & $\begin{array}{l}\text { Financial } \\
\text { education }\end{array}$ & $\begin{array}{l}\text { Financial } \\
\text { counseling }\end{array}$ & $\begin{array}{l}\text { Positive } \\
\text { effects }\end{array}$ & $\begin{array}{l}\text { Descriptive } \\
\text { Method }\end{array}$ & $\begin{array}{c}\text { Quasi- } \\
\text { experiments }\end{array}$ & $\begin{array}{l}\text { Randomized } \\
\text { Experiments }\end{array}$ & $\begin{array}{l}\text { Class } \\
\text { room }\end{array}$ & Online & Phone & $\begin{array}{c}\text { In } \\
\text { person }\end{array}$ & $\begin{array}{l}\text { Home } \\
\text { study }\end{array}$ \\
\hline $\begin{array}{l}\text { Basic Financial } \\
\text { education }\end{array}$ & 9 & 9 & 0 & 8 & 4 & 3 & 2 & 9 & 0 & 0 & 0 & 0 \\
\hline Homeownership & 9 & 1 & 8 & 8 & 2 & 7 & 0 & 3 & 0 & 4 & 7 & 2 \\
\hline Banking/ Credit & 4 & 3 & 1 & 3 & 2 & 1 & 1 & 2 & 1 & 1 & 1 & 0 \\
\hline Debtor/Bankruptcy & 3 & 3 & 1 & 3 & 2 & 1 & 0 & 2 & 0 & 1 & 0 & 0 \\
\hline
\end{tabular}


Table 5: Aggregated Synthesis of Studies by Format and Measures

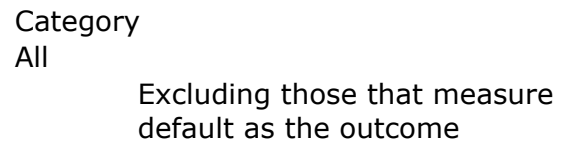

$\begin{array}{ccccc}\begin{array}{c}\text { Number } \\ \text { of } \\ \begin{array}{c}\text { Studies in } \\ \text { category } \\ 26\end{array}\end{array} & \begin{array}{c}\text { Measure } \\ \text { behaviors } \\ 23\end{array} & \begin{array}{c}\text { Measure } \\ \text { self- } \\ \text { reported } \\ \text { behavior } \\ 9\end{array} & \begin{array}{c}\text { Measure } \\ \text { financial } \\ \text { literacy } \\ 8\end{array} & \begin{array}{c}\text { Measure } \\ \text { Behavior } \\ \text { and } \\ \text { Literacy }\end{array} \\ 19 & 16 & 6 & 8 & 5 \\ 16 & 13 & 9 & 8 & 5 \\ 10 & 10 & 1 & 1 & 5\end{array}$

